\title{
Occurrence and synoptic background of strong and very strong frost in spring and autumn in Central Europe
}

\author{
Arkadiusz M. Tomczyk ${ }^{1}$ (D) $\cdot$ Katarzyna Szyga-Pluta $^{1} \cdot$ Ewa Bednorz $^{1}$ \\ Received: 3 January 2019 / Revised: 9 July 2019 / Accepted: 26 August 2019 / Published online: 12 September 2019 \\ (C) The Author(s) 2019
}

\begin{abstract}
The objective of the paper was the determination of the circulation conditions of occurrence of strong and very strong frost in Central Europe. A frost day was defined as a day with the minimum temperature lower than $0{ }^{\circ} \mathrm{C}$ and maximum temperature higher than $0{ }^{\circ} \mathrm{C}$. Moreover, a division of frost was performed in terms of value of minimum temperature, resulting in the designation of mild frost (up to $-2.0^{\circ} \mathrm{C}$ ), moderate frost (from -2.1 to $-4{ }^{\circ} \mathrm{C}$ ), strong frost (from -4.1 to $-6{ }^{\circ} \mathrm{C}$ ) and very strong frost $\left(<-6{ }^{\circ} \mathrm{C}\right)$. The study was based on data from the years 1966-2015 from the Institute of Meteorology and Water Management-National Research Institute, Deutscher Wetterdienst and National Center for Environmental Prediction/ National Center for Atmospheric Research (NCEP/NCAR). The analysis of baric conditions employed values of pressure at sea level, height of isobaric surface of $500 \mathrm{hPa}$ and air temperature at a level of $850 \mathrm{hPa}$, as well as their anomalies. The spatial analysis showed that the number of frost days in spring and autumn increased from the west to the east of Central Europe. A decrease in the number of frost days, however, is observed over the prevailing area. Average conditions favouring the occurrence of strong and very strong frost both in spring and autumn were related to higher than average pressure at sea level over the prevailing area of the Euro-Atlantic sector. Such baric conditions caused advections of cool air masses from the northern sector.
\end{abstract}

Keywords Spring and autumn frost $\cdot$ Circulation conditions $\cdot$ Climate change $\cdot$ Central Europe

\section{Introduction}

Contemporary climate change is unquestionable and evident, among others, in the observed increase in mean global air temperature (IPCC 2013). Global warming is also expressed in the declining number of frost days and in the lengthening of the frost-free seasons (Scheifinger et al. 2003; Jylhä et al. 2008; Potop et al. 2014; Tomczyk et al. 2015; Wypych et al. 2017; Bielec-Bakowska et al. 2018) and vegetation seasons (Goergen et al. 2013; Tomczyk and Szyga-Pluta 2018). Scheifinger et al. (2003) evidenced that in the second half of the twentieth (1951-1997) century, changes in the date of

Electronic supplementary material The online version of this article (https://doi.org/10.1007/s00484-019-01793-z) contains supplementary material, which is available to authorized users.

Arkadiusz M. Tomczyk

atomczyk@amu.edu.pl

1 Department of Climatology, Institute of Physical Geography and Environmental Planning, Adam Mickiewicz University in Poznań, B. Krygowskiego 10, 61-680, Poznan, Poland occurrence of the last day with spring frost in Central Europe fluctuated at a level of 2 days $/ 10$ years. The latest studies show the intensification of the changes, reaching approximately 5 days $/ 10$ years in the west of the country in recent years (1951-2010) (Wypych et al. 2017). Temperature increase can have serious consequences for vegetation, because air temperature not only does stimulate the cycle of growth of plants but also constitutes a potential threat to them, e.g. through the risk of occurrence of hot days during the vegetative season or late frost in the early beginning of the vegetative season (Scheifinger et al. 2003; Barlow et al. 2015). Increase in temperature in winter and early spring and, consequently, earlier commencement of the frost-free season and vegetation season are of particular importance for the development of plants. It determines the duration of the dormant period and the length of the period of plants development (Chmielewski et al. 2004). The occurrence of late spring frost in combination with increasingly frequent and mild winters constitutes a challenge even for frost-resistant plant species (Burroughs 2002).

The temperature decrease below $0{ }^{\circ} \mathrm{C}$ is one of the most dangerous weather conditions for plants in the vegetative season (Schnelle 1963, after Kalma et al. 1992; Dudek et al. 
2012; Chmielewski et al. 2018). The threat of frost to crops particularly occurs at the stage of their sprouting and blooming and in some species also at the stage of ripening (Koźmiński and Trzeciak 1971). The spring air temperature increase causes the beginning of the ontogenetic development. In the beginning, the water content in buds increases and as a consequence, the first visible changes occur (Chmielewski and Götz 2017). From this stage of development, the resistance of buds to cold continuously decreases (e.g. Dennis and Howell 1974; Proebsting and Mills 1978; Longstroth and Perry 1996; Miranda et al. 2005; Chmielewski et al. 2018). The occurrence of frost before the onset of blooming may cause damage to flower buds, but the damage is even larger in the blooming period, when frost may lead to complete loss of crop yield (Chmielewski et al. 2004; Matzneller et al. 2016). At mid-latitudes, most damage occurs during the spring bloom season, when below-freezing temperatures harm flower buds after the loss of cold hardiness; in a changing climate, this risk will remain, due to increasing variance of temperature (Rigby and Porporato 2008).

According to Proebsting (1982), even a single case of frost can lead to losses in efficiency of up to $90 \%$ in the case of production of stone fruits. Moreover, frost causes general weakening of the plant organism, resulting in a decrease in its resistance both to diseases and to an effect of unfavourable environmental conditions (Kreyling et al. 2012); damaged tissues also facilitate penetration by, e.g. parasites (Doroszewski et al. 2013).

In Central Europe, both winter and the transient seasons are characterized by high intra- and inter-annual weather variabilities. It is due to the atmospheric circulation, determining an inflow of air-masses of oceanic, continental, or Arctic origin. Therefore, pressure patterns and circulation conditions are the dominant factors modifying weather regime in local and regional scales. The influence of circulation on thermal conditions in Europe, including the occurrence of extremes, has been an object of several studies. It was evidenced that the vulnerability to frequent and rapid weather changes is a key feature of the European climate, related to dynamic circulation conditions (Buishand and Brandsma 1997; Niedźwiedź 2000; Wibig 2001; Huth et al. 2008; Ustrnul et al. 2010). Such rapid day-to-day changes in air temperature (particularly decreases below freezing point) during spring and autumn are strongly relevant to climate-related branches of human activity, particularly agriculture.

The objective of the paper was to determine the temporal and spatial variabilities of occurrence of spring and autumn frost in Central Europe and, secondly, to work out synoptic and circulation conditions causing strong and very strong frost in the studied area. Synoptic conditions were described throughout the air temperature and pressure patterns on different levels in the troposphere. The anomaly-based method, showing departures of sea level pressure and geopotential heights, as well as departures of temperature on horizontal and vertical cross sections through the troposphere, was applied. Additionally, analysis of antecedent conditions of the frost occurrence was performed by showing the tracks of temperature anomaly centres predating spring and autumn frost in Central Europe.

Research on the frequency and reasons of the extreme weather, which trigger risk for growing and for natural vegetation, is essential for agriculture and bioclimatology of plants. Due to the threat of strong and very strong frost, particularly in the case of crops, the study results, with the feedback of future circulation models, may help understand weather risk in the transient seasons and therefore they can be useful for a broad group of recipients.

\section{Data and methods}

The study was based on values of maximum $\left(T_{\max }\right)$ and minimum air temperature $\left(T_{\min }\right)$ from 40 stations in Central Europe from the period 1966-2015 (in the case of two stations - Kassel, Elblag —in the years 1966-2013) (Fig. 1). Data verified in terms of quality and homogeneity were obtained from the resources of the Institute of Meteorology and Water Management-National Research Institute (IMGWPIB) for the stations in Poland and from Deutscher Wetterdienst for the stations in Germany.

A frost day is defined as a day with minimum temperature lower than $0{ }^{\circ} \mathrm{C}$ and maximum temperature higher than $0{ }^{\circ} \mathrm{C}$ (Kossowska-Cezak 2003). Moreover, a division of frost was performed in terms of the value of minimum temperature into mild frost (up to $-2.0^{\circ} \mathrm{C}$ ), moderate frost (from -2.1 to $4{ }^{\circ} \mathrm{C}$ ), strong frost (from -4.1 to $-6{ }^{\circ} \mathrm{C}$ ) and very strong frost $\left(<-6{ }^{\circ} \mathrm{C}\right)$ (Dragańska et al. 2004). Then, the number of days with frost in particular categories in the spring season (AprilMay) and autumn season (September-October) was calculated. Moreover, sequences of days with strong and very strong frost were designated. Next, the multi-annual course of the number of days with frost was analysed, including the tendency of changes and variability of the frequency of occurrence of frost in particular categories. The assessment of statistical significance of changes employed a non-parametric MannKendall test applied for the analysis of data with a distribution deviating from normal, and their statistical significance was assessed by means of the Sen method at a level of $\alpha=0.05$.

Then, the baric conditions causing the occurrence of strong and very strong frost in spring and autumn were analysed. Spring/autumn frost often appears as a local phenomenon. For the purpose of eliminating days on which the considered frost occurred locally from the study, the analysis covered only days on which frost occurred at least in $10 \%$ of stations. Therefore, only days, when frost occurred in at least four stations, were taken into further synoptic analysis. 


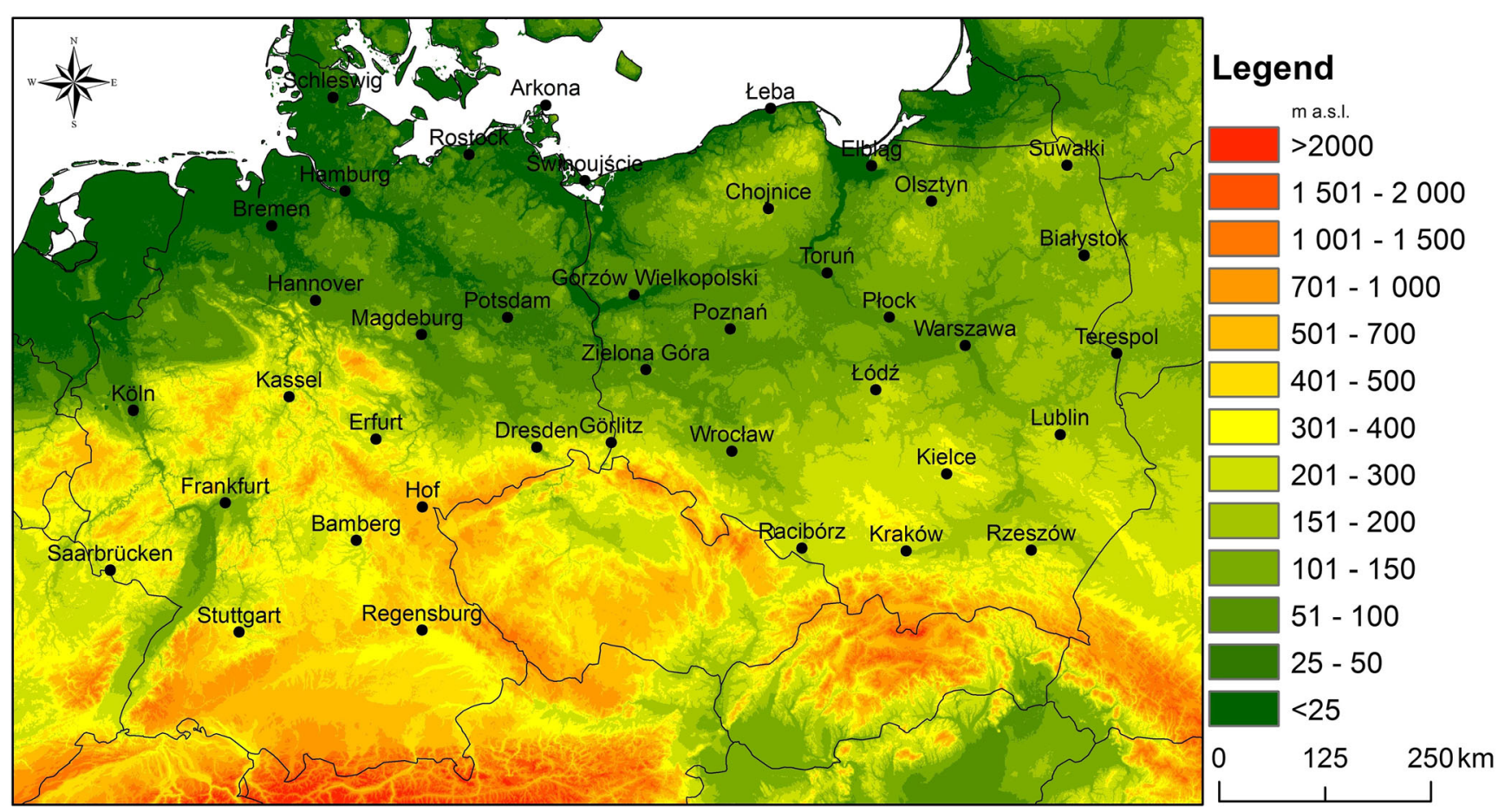

Fig. 1 Location of meteorological stations

Considering that the distance between neighbouring stations exceeds $100 \mathrm{~km}$ for most of them, the threshold of at least four stations eliminates local appearance of the analysed phenomenon.

The analysis of baric conditions employed average daily values of atmospheric pressure at sea level and heights of geopotential levels: 1000, 925, 850, 700, 600, 500, 400, $300,250,200,150,100$ and $70 \mathrm{hPa}$, as well as air temperatures at the specified levels. Data for nodes of the geographic grid $2.5 \times 2.5^{\circ}$ for the area $25-75^{\circ} \mathrm{N}$ and $35^{\circ} \mathrm{W}-65^{\circ} \mathrm{E}$ were obtained from the collection of the National Center for Environmental Prediction/National Center for Atmospheric Research (NCEP/NCAR) Reanalysis (Kalnay et al. 1996) available in the archives of NOAA ESRL PSD (Earth System Research Laboratory Physical Science Division).

Based on the above data, cross sections through the atmosphere were designated (from the level of $1000 \mathrm{hPa}$ do the level of $70 \mathrm{hPa}$ ) with anomalies of geopotential heights and air temperature along three meridians $\left(10,15,20^{\circ} \mathrm{E}\right)$ and one parallel $\left(52.5^{\circ} \mathrm{N}\right)$ separately for strong and very strong frost in spring and autumn. Then, average maps of sea-level pressure (SLP) and $500 \mathrm{hPa}$ geopotential height (z500 hPa) and maps of anomalies of the above parameters and air temperature at $850 \mathrm{hPa}$ geopotential height (T850) for spring and autumn cases were prepared. All anomalies were calculated as a difference between mean sea level pressure value on a particular day, heights of isobaric surfaces and air temperature on such levels and mean value of the aforementioned elements on a given day in the studied multi-annual period. At the next stage, circulation types were designated through grouping particular days in terms of values of sea level pressure with the application of the minimum variances method known as the Ward method (1963). For the designated types, maps of average SLP, z500 hPa and T850 were prepared, as well as maps of anomalies. Then, for the longest series of days (waves) with strong and very strong frost, maps were prepared with courses of movement of centres of anomalies of T850 on days preceding their occurrence in a given area.

\section{Results}

\section{Occurrence of spring frost}

The number of frost days in the spring season in Central Europe in the years 1966-2015 increased from the west to the east, from 67 days in Rostock to 571 days in Białystok (Table 1). It was also larger in stations located higher a.s.l. (e.g. Hof, 517 days). The highest number of spring frost days occurred in 1997 (in 10 stations) and 1981 (in 7 stations) (Fig. 2). The maximum number of spring frost days varied from 8 days in Rostock (1970) and 9 days in Kassel (1997, 2008) and Świnoujście (1996) to 26 days in Olsztyn (1980), 24 days in Kielce (1980) and 23 days in Hof (1973).

Over the prevailing area of Central Europe, a decrease in the number of days with frosts in spring was observed. It was statistically significant in 55\% of stations. Only in 1 station (Terespol), located in the east of the study area, an increasing 
Table 1 Total number of spring and autumn frost days in particular categories in Central Europe (1966-2015)

\begin{tabular}{|c|c|c|c|c|c|c|c|c|c|c|c|}
\hline \multirow[t]{2}{*}{ Country } & \multirow[t]{2}{*}{ Station } & \multicolumn{4}{|c|}{ Spring } & \multicolumn{4}{|c|}{ Autumn } & \multicolumn{2}{|l|}{ Total } \\
\hline & & Mild & Moderate & Strong & Very strong & Mild & Moderate & Strong & Very strong & Spring & Autumn \\
\hline \multirow[t]{19}{*}{ Germany } & Arkona & 83 & 13 & 0 & 0 & 5 & 0 & 0 & 0 & 96 & 5 \\
\hline & Bamberg & 228 & 119 & 34 & 7 & 140 & 52 & 17 & 7 & 388 & 216 \\
\hline & Bremen & 175 & 63 & 17 & 7 & 68 & 21 & 8 & 5 & 262 & 102 \\
\hline & Dresden & 144 & 50 & 10 & 1 & 70 & 17 & 4 & 0 & 205 & 91 \\
\hline & Erfurt & 221 & 92 & 29 & 5 & 93 & 44 & 10 & 3 & 347 & 150 \\
\hline & Frankfurt & 142 & 45 & 11 & 1 & 84 & 19 & 3 & 0 & 199 & 106 \\
\hline & Gorlitz & 208 & 50 & 23 & 1 & 108 & 35 & 14 & 0 & 282 & 157 \\
\hline & Hamburg & 189 & 66 & 11 & 5 & 79 & 23 & 4 & 3 & 271 & 109 \\
\hline & Hannover & 170 & 86 & 21 & 5 & 78 & 31 & 7 & 3 & 282 & 119 \\
\hline & Hof & 338 & 129 & 40 & 10 & 148 & 75 & 17 & 4 & 517 & 244 \\
\hline & Kassel & 135 & 36 & 3 & 3 & 72 & 13 & 0 & 2 & 177 & 87 \\
\hline & Köln & 190 & 70 & 18 & 4 & 79 & 26 & 11 & 0 & 282 & 116 \\
\hline & Magdeburg & 154 & 51 & 19 & 2 & 92 & 22 & 5 & 2 & 226 & 121 \\
\hline & Potsdam & 155 & 47 & 8 & 0 & 59 & 21 & 3 & 0 & 210 & 83 \\
\hline & Regensburg & 193 & 55 & 13 & 1 & 128 & 39 & 9 & 0 & 262 & 176 \\
\hline & Rostock & 58 & 9 & 0 & 0 & 14 & 0 & 0 & 0 & 67 & 14 \\
\hline & Saarbrucken & 149 & 47 & 7 & 0 & 66 & 16 & 0 & 1 & 203 & 83 \\
\hline & Schleswig & 189 & 46 & 6 & 0 & 32 & 16 & 1 & 0 & 241 & 49 \\
\hline & Stuttgart & 175 & 55 & 6 & 1 & 91 & 37 & 8 & 1 & 237 & 137 \\
\hline \multirow[t]{21}{*}{ Poland } & Białystok & 331 & 166 & 50 & 24 & 197 & 115 & 40 & 33 & 571 & 385 \\
\hline & Chojnice & 292 & 110 & 34 & 6 & 131 & 56 & 10 & 2 & 442 & 199 \\
\hline & Elblag & 219 & 77 & 17 & 1 & 115 & 32 & 4 & 2 & 314 & 153 \\
\hline & Gorzów Wlkp. & 170 & 60 & 11 & 0 & 90 & 36 & 8 & 0 & 241 & 134 \\
\hline & Kielce & 309 & 132 & 45 & 14 & 184 & 93 & 32 & 12 & 500 & 321 \\
\hline & Kraków & 315 & 79 & 16 & 2 & 248 & 85 & 24 & 4 & 412 & 361 \\
\hline & Lublin & 219 & 85 & 9 & 4 & 159 & 82 & 20 & 8 & 317 & 269 \\
\hline & Łeba & 231 & 119 & 30 & 4 & 83 & 24 & 1 & 0 & 384 & 108 \\
\hline & Łódź & 205 & 92 & 23 & 3 & 133 & 65 & 13 & 6 & 323 & 217 \\
\hline & Olsztyn & 282 & 170 & 36 & 14 & 142 & 83 & 21 & 8 & 502 & 254 \\
\hline & Płock & 202 & 88 & 13 & 1 & 131 & 56 & 10 & 3 & 304 & 200 \\
\hline & Poznań & 196 & 96 & 28 & 9 & 116 & 42 & 21 & 8 & 329 & 187 \\
\hline & Racibórz & 162 & 73 & 9 & 0 & 120 & 29 & 18 & 4 & 244 & 171 \\
\hline & Rzeszów & 236 & 102 & 41 & 5 & 138 & 88 & 29 & 14 & 384 & 269 \\
\hline & Suwałki & 331 & 162 & 47 & 15 & 192 & 109 & 40 & 16 & 555 & 357 \\
\hline & Świnoujście & 116 & 33 & 2 & 0 & 38 & 5 & 0 & 0 & 151 & 43 \\
\hline & Terespol & 247 & 85 & 23 & 2 & 193 & 94 & 38 & 13 & 357 & 338 \\
\hline & Toruń & 271 & 133 & 50 & 16 & 142 & 69 & 23 & 14 & 470 & 248 \\
\hline & Warszawa & 201 & 91 & 19 & 0 & 138 & 78 & 17 & 8 & 311 & 241 \\
\hline & Wrocław & 217 & 88 & 34 & 6 & 120 & 59 & 28 & 9 & 345 & 216 \\
\hline & Zielona Góra & 148 & 39 & 13 & 0 & 77 & 22 & 4 & 0 & 200 & 103 \\
\hline Average & & 205 & 80 & 21 & 4 & 110 & 46 & 13 & 5 & 310 & 173 \\
\hline
\end{tabular}

tendency was determined, although it was not statistically significant.

A lower frequency of spring frost was characteristic of the western coast of the Baltic Sea from Schleswig to Świnoujście together with stations located in the central part of the study area, as well as the south-western part. Spring frost occurred the most frequently in the north-east of Poland (Białystok, Suwałki and Olsztyn) and in the south-eastern part of 
Białystok

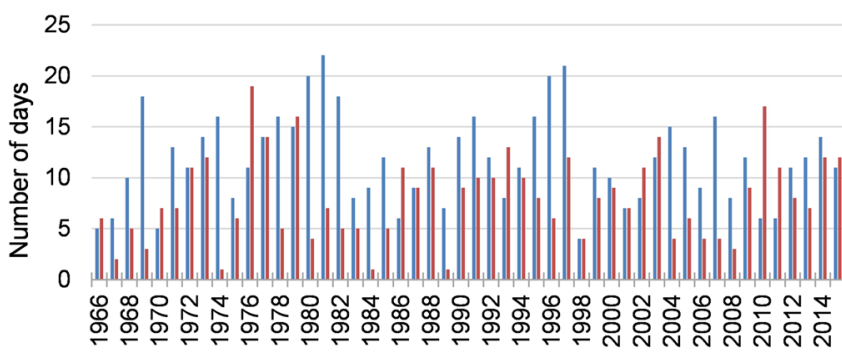

Hof

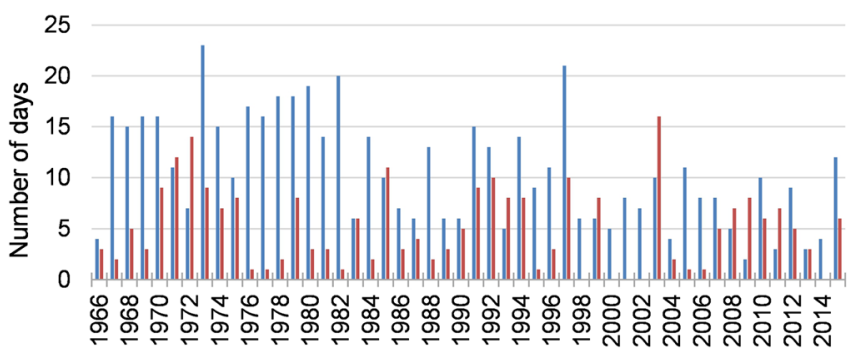

Schleswig

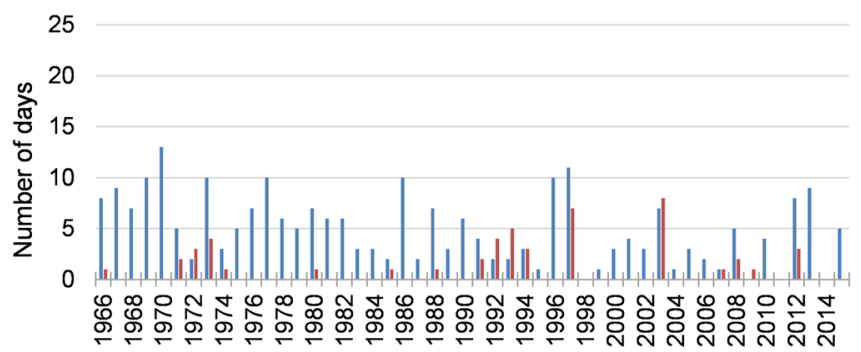

Frankfurt

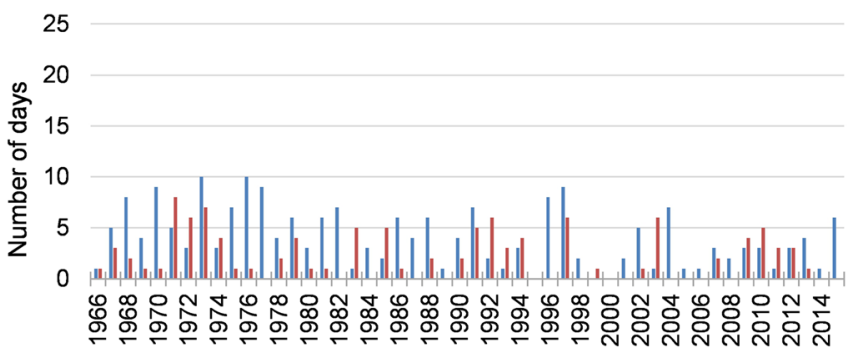

Potsdam

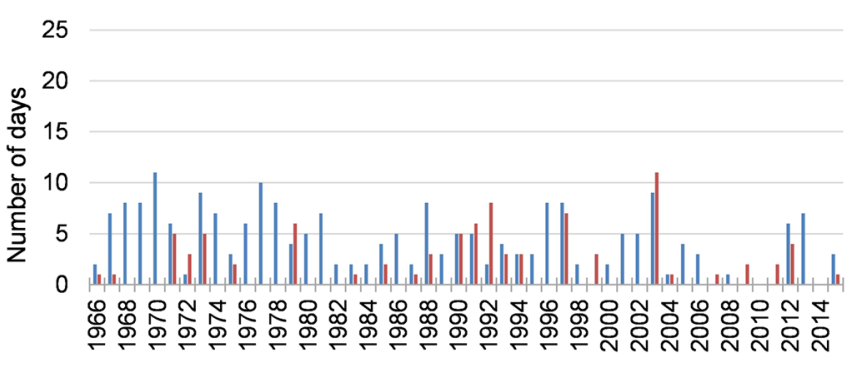

Terespol

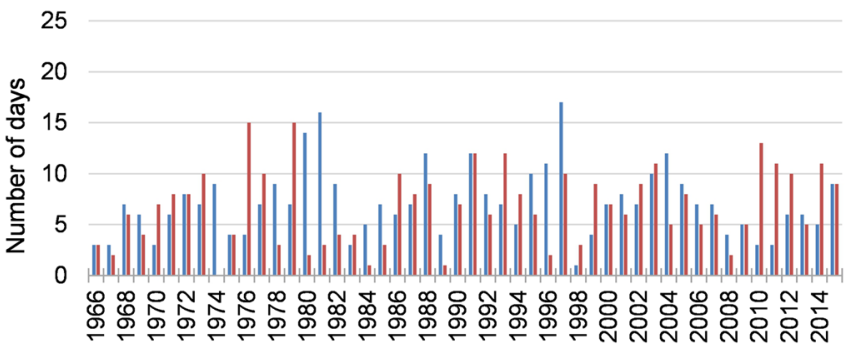

= spring a autumn

Fig. 2 Annual number of spring and autumn frost days in selected stations (1966-2015)

Germany (Hof, Erfurt and Bamberg). Mild frost was the most frequent in spring — averaging 205 days in the period 1966-2015 in Central Europe (Table 1). Their highest number was recorded in the station located the highest - Hof (338 days) — and the lowest in Rostock (58 days). Moderate frost occurred 80 days on average in the study period. Their number varied from 166 days in Białystok to 13 days in Arkona. Strong frost was the most frequent in Białystok and Torun (50 days), and in Rostock, it was not recorded at all. The average number of days with strong frost in spring was 21 . Very strong frost occurred on average 4 days in the spring period, particularly in the north-eastern part of the analysed area (24 days in Białystok) and in areas located higher (10 days in Hof). They particularly occurred in April. In May, only 2 days were recorded in Toruń. In a vast majority of stations, single days with strong and very strong frost were predominant. In two stations, i.e. in Elblag and Świnoujście, all days with strong and very strong frost were recorded as single cases. The longest sequence of days with the analysed frost occurred in Rzeszów in 1974 from 14 to 18 April. Four-day sequences were also recorded in several stations (Bamberg, Bremen, Hof, Kielce, Suwałki). In the study period, during 4 days, the occurrence of strong and very strong frosts in at least half of the analysed stations was recorded. They particularly occurred in the central belt of the study area, extending from west Germany to east Poland. An exception was 8.04.1997, when the analysed frosts occurred mainly $(81 \%)$ in the territory of Poland.

\section{Impact of the circulation on the occurrence of strong and very strong frost in spring}

For the analysis of synoptic background of frost occurrence, the days with frost were selected along the particular criteria namely, occurrence of strong and very strong frost $\left(<4{ }^{\circ} \mathrm{C}\right)$ in at least $10 \%$ of stations within the research area. This allowed to appoint 93 cases of frost occurrence in spring and 64 cases in autumn.

The occurrence of strong and very strong frost in spring was related to lower-than-normal height of geopotential levels in the entire vertical profile taken to the analysis (Fig. 3). The greatest 
negative anomalies were recorded in the upper troposphere, at the height of $300-250 \mathrm{hPa}$, and their extremes were identified along meridian $20^{\circ} \mathrm{E}(<-120 \mathrm{gpm})$. The centre of the negative anomalies was located over eastern Poland, and it extended to the north-east. Negative anomalies throughout the entire vertical profile, however, covered the area located south of $47^{\circ} \mathrm{N}$. In the air column below the centre of negative geopotential anomalies, i.e. below the level of $250 \mathrm{hPa}$, negative anomalies of air temperature were recorded over the prevailing area of the continent. The greatest anomalies were observed on the lowest geopotential levels $(1000-850 \mathrm{hPa})$, where air temperature was lower by even $>6{ }^{\circ} \mathrm{C}$ than on average in the multi-annual period. The centre of the anomalies was located over the south-eastern part of the study area. In the upper troposphere (above the isobaric level of $250 \mathrm{hPa}$ ), positive air temperature anomalies occurred, exceeding at most $2{ }^{\circ} \mathrm{C}$. This is a typical vertical pattern of temperature anomalies in the high-pressure system, and it is caused by the convergence of warmer air masses in the upper troposphere, over the subsidence zone in the anticyclonic centre.

During the occurrence of strong and very strong frost in spring, the Euro-Atlantic sector was under the influence of the expanded and slightly shifted towards the north (comparing to the average pressure pattern) high-pressure wedge within which a local high developed over the British Isles (> $1018 \mathrm{hPa}$ ) (Fig. 4). Simultaneously, over north Europe and the Mediterranean Sea, shallow low-pressure systems were located. On the analysed days, over a considerable part of western, central and northern Europe, and the ocean, SLP was higher than the multi-annual mean. In the centre of the high-pressure system, anomalies exceeded $4 \mathrm{hPa}$. Over the study area, SLP was higher than average from approximately $1 \mathrm{hPa}$ in the south to around $4 \mathrm{hPa}$ in the north-west. The isohips of the isobaric surface of
$500 \mathrm{hPa}$ over the major area of Central Europe were bent towards the south, creating a distinct depression. Negative anomalies of z500 hPa ran through the north-east to the south-west and their centre $(<-80 \mathrm{gpm})$ covered among others the eastern part of the analysed area. The described baric situation generated advection of cool air masses from the northern sector. The course of anomalies of T850 suggests advection from the north-eastern sector. Negative anomalies of T850 covered the entire study area, and their centre particularly covered east and south-east Poland $(<-$ $\left.6{ }^{\circ} \mathrm{C}\right)$.

Detailed research on circulation conditions led to the designation of two types of circulation favouring the occurrence of strong and very strong frost in spring. Seventy-four percent of the analysed cases were classified in type 1 and the remaining $26 \%$ in type 2 . In type 1 , a high-pressure system persisted over the British Isles (> $1020 \mathrm{hPa}$ in the centre), with simultaneous occurrence of a low over the Mediterranean Sea $(<1009 \mathrm{hPa})$ (Fig. 4). The area north of $47^{\circ} \mathrm{N}$ was covered by positive SLP anomalies, exceeding $8 \mathrm{hPa}$ in the centre. Over the southern regions, SLP was lower than average, by more than $4 \mathrm{hPa}$ in the centre, while in Central Europe, SLP anomalies varied from 0 to $5 \mathrm{hPa}$. In type 2 , the key role in shaping weather conditions was played by two baric systems, i.e. high-pressure wedge, shifted southwards of an average position and a low with a centre located east of Iceland (<995 hPa) (Fig. 4). The high-pressure wedge brought the radiative conditions under the clear sky in the subsidence zone, which contributed to lowering temperature. At the same time, both positive (in the south) and negative (in the north) pressure anomalies resulted in high horizontal pressure gradient causing strong advection of air masses from the northwest. The pressure difference between the described centres of anomalies was more than $20 \mathrm{hPa}$, and over the study area, SLP
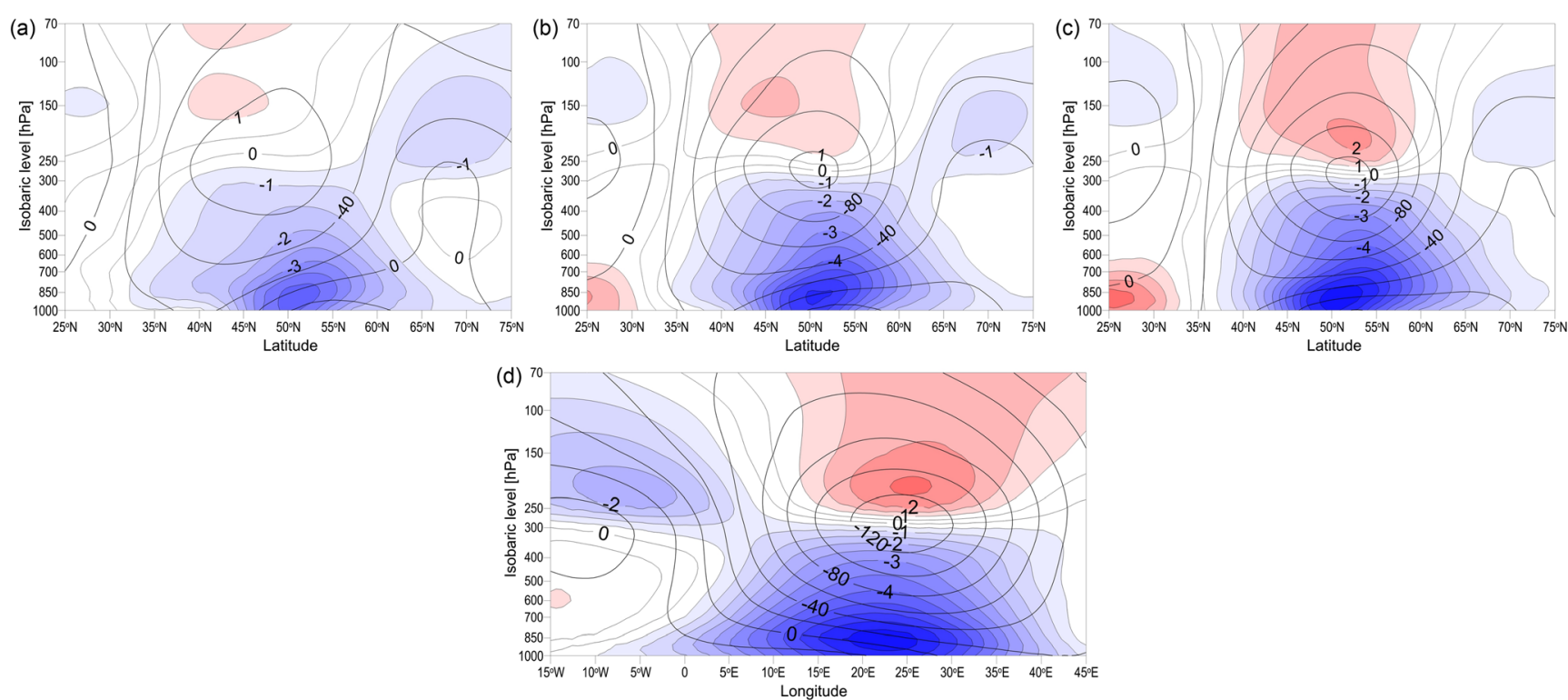

Fig. 3 Vertical cross sections through the troposphere with mean anomalies of heights of isobaric surfaces (black lines) and air temperature (colour scale) along meridians $10,15,20^{\circ} \mathrm{E}(\mathbf{a}-\mathbf{c})$ and parallel $52.5^{\circ} \mathrm{N}(\mathbf{d})$ during the analysed days with strong/very strong frost in spring 
(a)

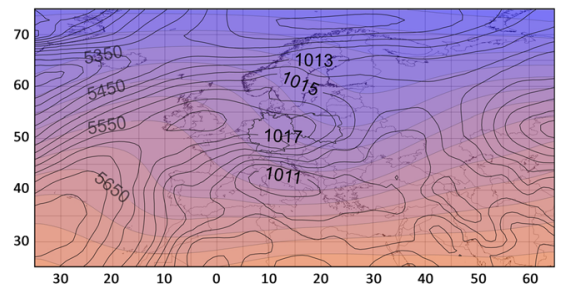

(b)

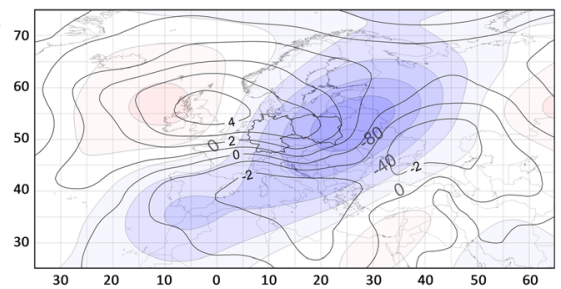

(c)

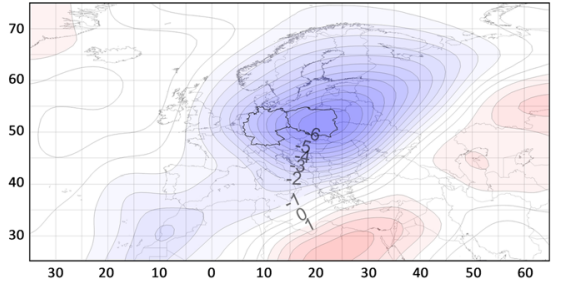

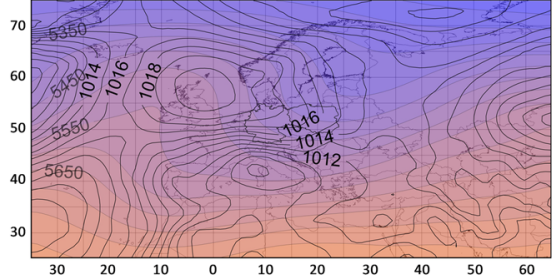
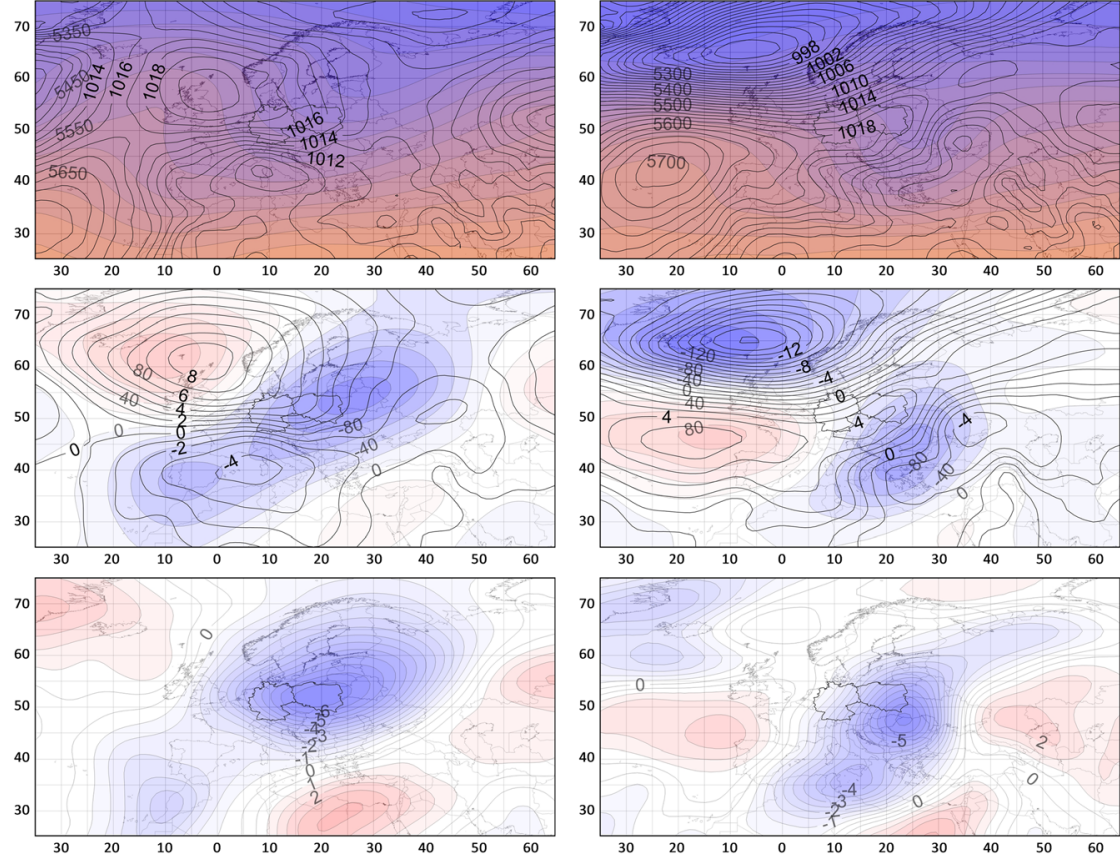

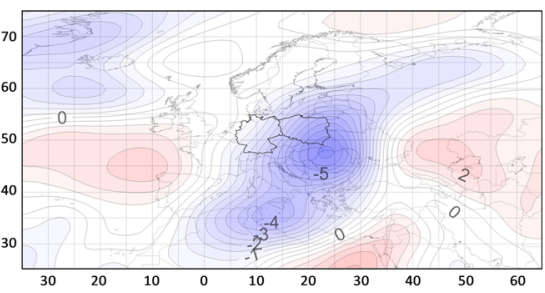

Fig. 4 Mean SLP (black lines) and z500 hPa (colour shades) (a); anomalies of SLP (black lines) and z500 hPa (colour shades) (b); and anomalies of T850 (colour shades) (c) during the all analysed days with strong/very strong frost in spring (left column) and for types 1 (middle column) and 2 (right column)

anomalies varied from 0 to more than $4 \mathrm{hPa}$. Both in types 1 and 2, isohips of the isobaric surface $500 \mathrm{hPa}$ were bent southwards, although in type 2 , the system was shifted somewhat to the east. In type 1 , the entire study area remained within the range of negative anomalies of z500 hPa with the centre extending from south-west Poland to west Russia ( $<-100$ gpm). A different situation was determined in type 2, where the western part of the study area was within the range of positive anomalies and the eastern one in the range of negative anomalies with the centre over the Balkan Peninsula (<-80 gpm). The designated types caused advection of cool air masses that in type 1 particularly persisted over Central Europe and in type 2 over Central and south Europe. Both in types 1 and 2, the negative anomalies of T850 were recorded over the entire study area (the greatest over Poland), whereas in type 2 particularly over the south-eastern part of the study area. Consequently, type 1 made favourable conditions for strong and very strong frost all over Central Europe, while at type 2, strong and very strong frost appeared mainly in stations located in eastern, south eastern and central Poland.

For the longest periods of days with strong and very strong frost, the air temperature (T850) anomalies in the days preceding the frost events were computed and the locations of the centres of T850 negative anomalies were identified. In 3 out of 4 of the selected spring frost cases, the centres of T850 anomalies moved from the north or north-west towards the study area and in one case from the east (Fig. 5). The development of anomalies of T850 lasted from 2 days (in 1986) to 4 days (in 1988 and 2002) before the occurrence of the wave of the frost days in Central Europe. At the beginning, the formed
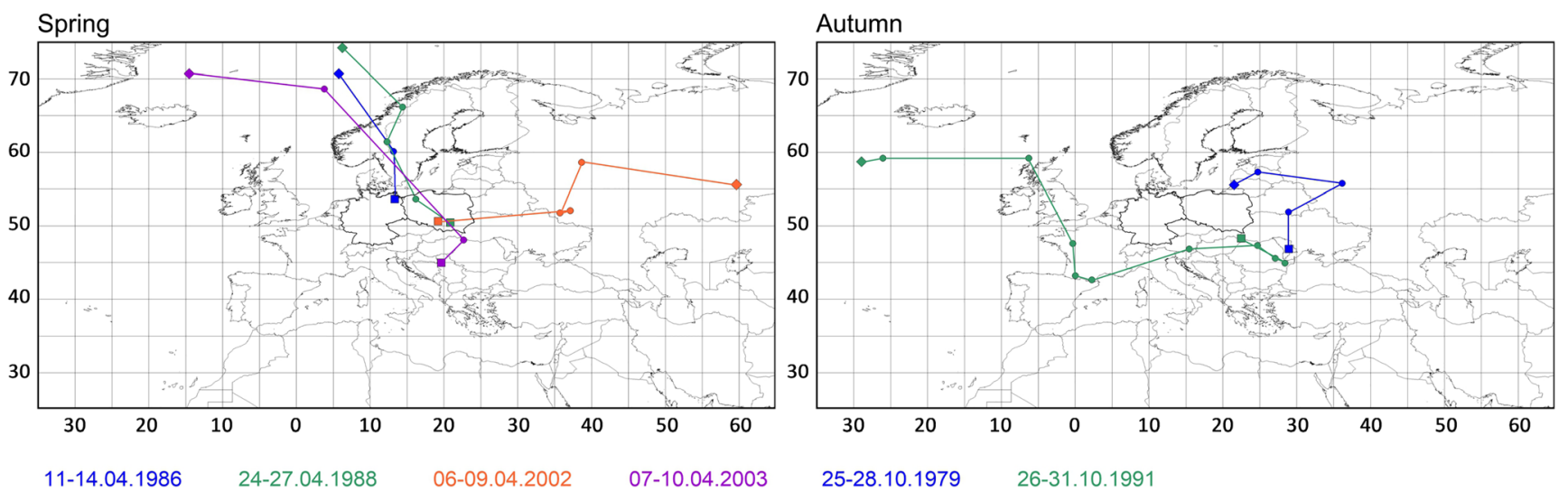

Fig. 5 Selected tracks of T850 anomaly centres on days preceding the occurrence of frost waves (rhombus - development of the centre of anomalies, square - first day of the waves) in spring and autumn 
T850 anomalies were weak and they strengthened over the studied area; their highest values were usually recorded on the first day of the spring frost event, when the air temperature at $850 \mathrm{hPa}$ was lower than average from $11{ }^{\circ} \mathrm{C}$ (in 2002) to $13{ }^{\circ} \mathrm{C}$ (in 1986 and 2003).

\section{Occurrence of autumn frost}

The number of frost days in the autumn season (SeptemberOctober) in Central Europe in the years 1966-2015 also increased from the west to the east, from 5 days in Arkona to 385 days in Białystok (Table 1). The highest number of frost days occurred in 2003 (in 21 stations) and 1979 (in 11 stations). The maximum number of autumn frost days varied from 2 days in Arkona and 3 days in Rostock (2003) to 23 days in Suwałki and 19 days in Białystok and Kraków (1976).

Over the prevailing area of Central Europe, an increase in the number of days with frost in autumn was observed (Fig. 2 ); however, it was not statistically significant. Only in 8 stations, located in the west of the study area, a decreasing tendency was determined, although it was not statistically significant as well.

Autumn frost occurred the most frequently in the eastern part of Central Europe and the most seldom on the western coast of the Baltic Sea. Mild autumn frost was recorded 110 days on average in the study period. Their number varied from 5 days in Arkona to 197 in Białystok (Table 1). An average of 46 days of moderate frost occurred in autumn. They were the most frequent in Białystok (115 days) and Suwałki (109 days) and did not occur at all on the western coast of the Baltic Sea (Arkona, Rostock). Strong frost particularly occurred in October (13 days on average) - the most frequently in Białystok and Suwałki (40 days). In September, single days of frost from -4.1 to $-6{ }^{\circ} \mathrm{C}$ were recorded in stations located furthest in the east of the study area. The very strong frost occurred 5 days on average in autumn. They were the most frequent in Białystok (33 days). In a vast majority of stations, single days with strong and very strong frost were predominant. In seven stations, i.e. in Frankfurt, Gorzów Wielkopolski, Kassel, Łeba, Saarbrucken, Schleswig and Zielona Góra, all days with strong and very strong frost were recorded as single cases. The longest sequence of days with the analysed frost occurred in Suwałki in 1976 from 16 to 22 October. Five- and 4-day sequences were also recorded in several stations. In the study period, during 3 days, the occurrence of strong and very strong frosts in at least half of the analysed stations was recorded. They particularly occurred in the central belt of the study area, extending from west Germany to east Poland. An exception was 26 October 1988 , when the analysed frosts occurred mainly $(95 \%)$ in the territory of Poland.

\section{Impact of the circulation on the occurrence of strong and very strong frost in autumn}

Similarly as in the case of spring frost, the occurrence of strong and very strong autumn frost was related to a lowering of geopotential levels (Fig. 6). The greatest height anomalies were recorded in the upper troposphere, at the level of $250 \mathrm{hPa}$. Over the study area, the greatest deviations from the average height of geopotential levels was recorded over the eastern regions which along meridian $20^{\circ} \mathrm{E}$ amounted to $<$ $-100 \mathrm{~m}$. The centre of the entire system of anomalies, however, was located east of the study area, where the maximum anomalies exceeded $-160 \mathrm{gpm}$. The performed cross sections suggest that the greatest anomalies occurred in the south and south-east of the analysed area. Negative anomalies of geopotential heights indicate the presence of cooler air masses, which is as also confirmed by negative anomalies of air temperature, reaching extreme values at the lowest levels (1000-850 hPa); over the study area, they amounted to $-6{ }^{\circ} \mathrm{C}$.

The occurrence of strong and very strong autumn frost was related to the presence over Central Europe of a high-pressure system with the centre over west Ukraine (> $1024 \mathrm{hPa}$ ) (Fig. 7). On the analysed 64 days with strong and very strong frost in autumn, the major part of the Euro-Atlantic sector was located within the range of positive SLP anomalies with the centre extending from north Poland to the Atlantic Ocean (> $7 \mathrm{hPa}$ ). Only over the southern regions, SLP lower than the multi-annual mean was recorded. Isohips of the isobaric surface of $500 \mathrm{hPa}$ over Central and particularly east Europe were evidently bent southwards, suggesting its lower persistence. Negative anomalies of z $500 \mathrm{hPa}$ ran from the north-east to the south-west, covering almost (except for the north-western region of Germany) entire study area. The centre of anomalies was located over north-east Ukraine and west Russia ( $<-$ $100 \mathrm{gpm})$. The described baric conditions caused advection of cool air masses from the north-east, due to clock ward circulation around the anticyclonic centre. The direction of advection is also suggested by the course of isoanomalies of T850. Negative anomalies of air temperature covered the entire study area. They varied from -1 to $<-6{ }^{\circ} \mathrm{C}$.

Further research led to the designation of two types of circulation favourable to autumn frost events. In type 1, explaining $64 \%$ of cases over Central Europe, a strong highpressure system persisted with the centre over east Poland and west Belarus and Ukraine (> 1029 hPa) (Fig. 7). Over the majority of the continent, SLP was higher than the multiannual mean. The maximum anomalies occurred over the southern regions of the Scandinavian Peninsula (>14 hPa), and over the study area, they varied from 4 to $13 \mathrm{hPa}$. Under anticyclonic conditions, the clear sky intensified radiation, which contributed to lowering temperature, together with the advection of cold air masses from the north-east, which were 

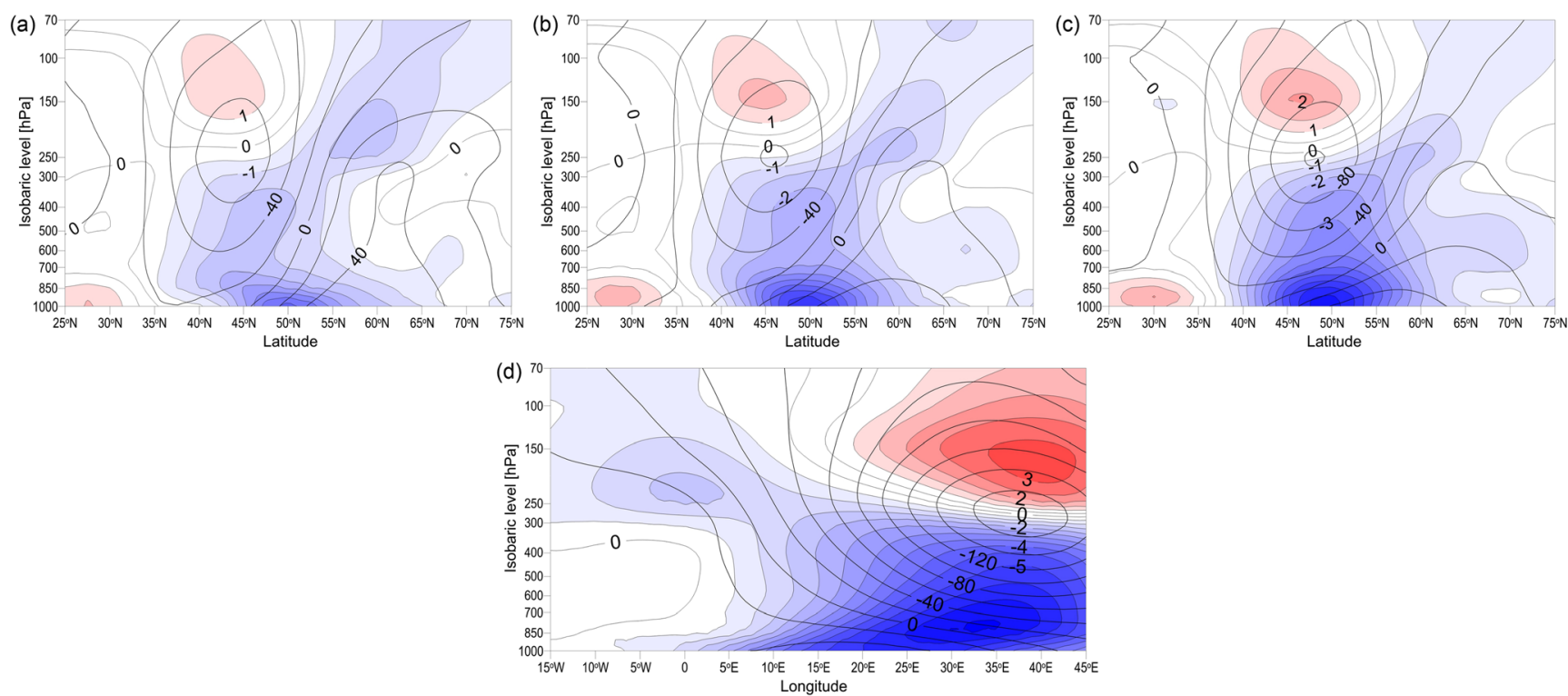

Fig. 6 Vertical cross sections through the troposphere with mean anomalies of heights of isobaric surfaces (black lines) and air temperature (colour scale) along meridians $10,15,20^{\circ} \mathrm{E}(\mathbf{a}-\mathbf{c})$ and parallel $52.5^{\circ} \mathrm{N}(\mathbf{d})$ during the analysed days with strong/very strong frost in autumn

transported to the study area by the clock ward circulation around the anticyclonic centre.

Similarly in type 2, causing $36 \%$ of cases (most of them occurring in the southern and south-eastern part of the analysed region), a high persisted over Central Europe, although it was considerably weaker and shifted southwards from the highs from type 1 and it encompassed the southern part of the studied area (Fig. 7). In the analysed cases, the low- pressure system with the centre over north Scandinavia was of dominant importance $(<1000 \mathrm{hPa})$. A high horizontal pressure gradient occurred between the aforementioned baric systems, intensifying advection of cool air masses from the northwest. Over the majority of the continent, SLP was lower than the multi-annual mean, and the centre of anomalies was located over north Sweden $(<-7 \mathrm{hPa})$. In both types, isohips of the isobaric surface were bent southwards, although they were (a)

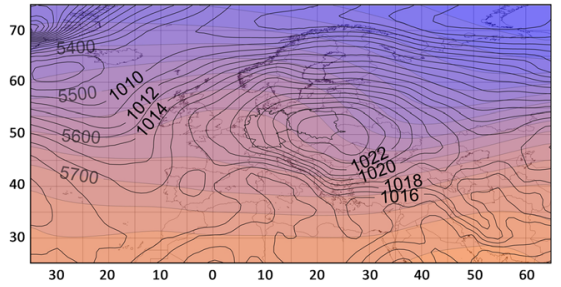

(b)

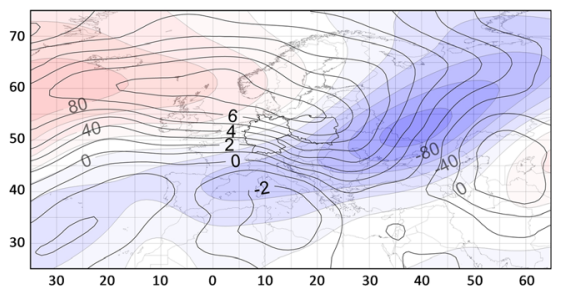

(c)

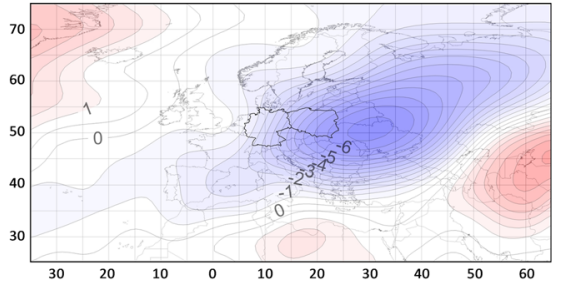

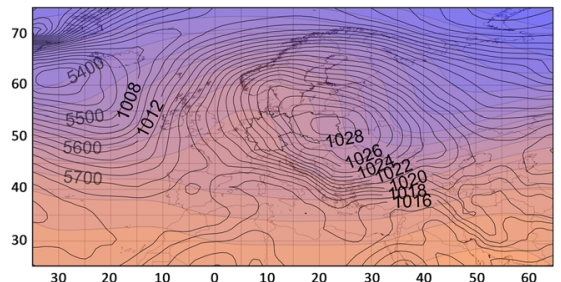
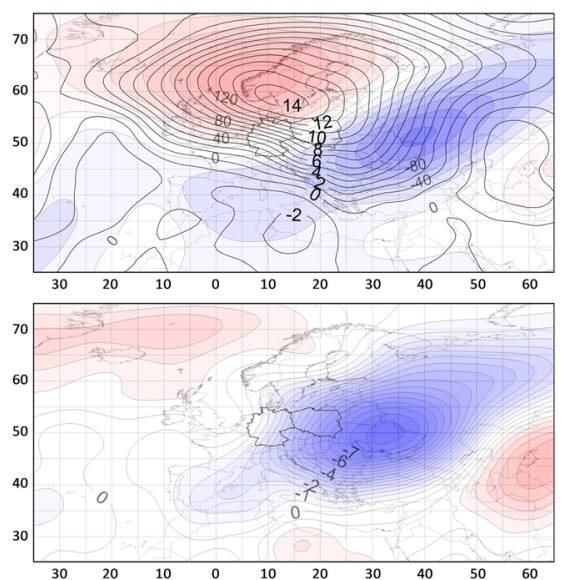
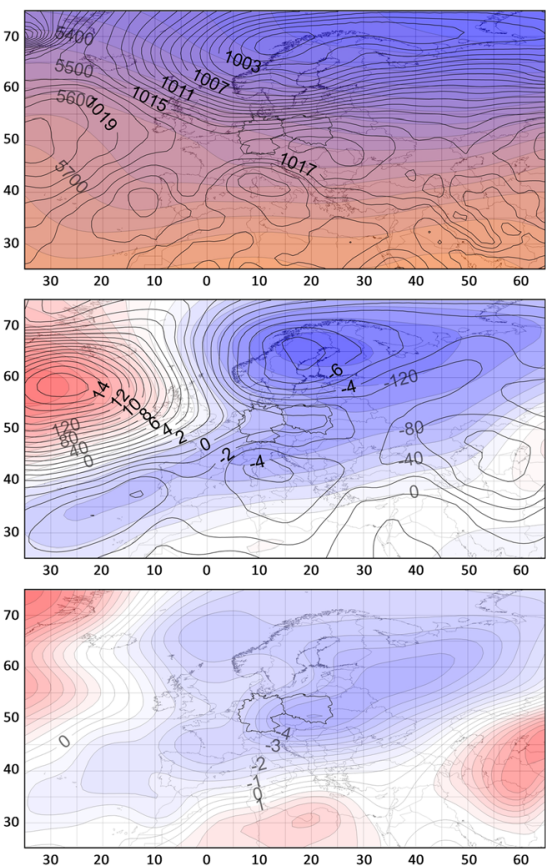

Fig. 7 Mean SLP (black lines) and z500 hPa (colour shades) (a); anomalies of SLP (black lines) and z500 hPa (colour shades) (b); and anomalies of T850 (colour shades) (c) during the all analysed days with

strong/very strong frost in autumn (left column) and for types 1 (middle column) and 2 (right column) 
more evident in type 1 . In type 1 in the Euro-Atlantic sector, 2 centres of anomalies of z500 hPa were observed, i.e. positive anomalies over the northern and north-western part and negative from east to south Europe. In type 2, almost the entire continent was within the range of negative anomalies of z500 hPa with the centre over north Sweden and Finland (< $-140 \mathrm{gpm}$ ). Both baric situations caused advection of cool air masses, whereas evidently cooler air flew in type 1 . This is suggested by anomalies of T850 with the centre in type 1 remaining over Ukraine and in type 2 over south Poland. In German stations, types 1 and 2 equally contributed to occurrence of strong and very strong frost, while in Poland, more frost days appeared under synoptic conditions of type 1 .

In autumn, the longest sequences of days with strong and very strong frost included 6 and 4 days, and for those cases, T850 anomalies in the preceding days were followed (Fig. 5). Anomalies of T850 before the commencement of the wave of the analysed frost days in 1979 began developing in the area of the Gulf of Riga and in 1991 in the area of Greenland. In the first case, they developed 3 days and, in the second case, 10 days before the commencement of the waves in Central Europe. In both cases, the centre of anomalies $\left(<-12{ }^{\circ} \mathrm{C}\right)$ on the first day of the frost wave persisted south-east of the study area.

\section{Discussion and summary}

Scenarios of climate changes for Europe show the tendency for a decrease in the threat related to frost as an effect of a considerable decrease of both the number of frost days and prolongation of the period without frost, as well as a decrease in the intensity of frost (Jylhä et al. 2008). The changes, however, do not occur evenly over the area of Europe.

The spatial analysis showed that the number of frost days in spring and autumn in the years 1966-2015 increased from the west to the east of Europe. It is a consequence of an increase in the continentalism of the climate towards the east. It was also higher in stations located at a highest altitude. However, the occurrence of frost days seems to be influenced mainly by local conditions rather than the location of the station above the sea level. The location of the station in the range of the sea impact reduces the number of days with frost. Over the majority of Central Europe, however, a decrease in the number of frost days was observed. Only in 3 stations, located in the east of the study area, an increasing tendency was determined. The analysis showed that spring frost occurred more often in Central Europe than autumn frost. In the western part of the study area, the number of spring frost events was prevalent. The further to the east, the more days of autumn frost occurred. Changes in the terms of frost lead to a change in the duration of the frost-free period. The greatest increase in the duration of the frost-free period is forecasted in areas where the period is currently the shortest (Graczyk and Kundzewicz 2016). A tendency for the earlier occurrence of the last frost was determined by Scheifinger et al. (2003) and a tendency for delaying the first autumn frost in Central Europe by Tomczyk et al. (2015). According to BielecBakowska and Piotrowicz (2011), the prolongation of the frostfree period results from an evident increase in air temperature in the 1990s. A decreasing tendency of the number of frost days is confirmed by earlier studies concerning both Europe (Heino et al. 1999; Tomczyk et al. 2015) and North America (Bonsal et al. 2001; Easterling 2002; Kunkel et al. 2004; Meehl et al. 2004) or China (Liu et al. 2008). In Central Europe, spring frost occurred more frequently than autumn frost, although their frequency is spatially variable. In the western part of the study area, spring frost was dominant. In the further east, the more cases of autumn frost were recorded. Spring frost poses a greater threat in the western part of the study area, where the frost-free and vegetation period begins earlier (Tomczyk et al. 2015; Wypych et al. 2017; Bielec-Bakowska et al. 2018; Tomczyk et al. 2018a) and the difference in the commencement of the periods between the eastern and western regions of Central Europe can be even more than a month. According to Wypych et al. (2017), such a spatial variability in Central Europe results from circulation factors.

Spring days with strong frost particularly occurred in April and in May only sporadically in east Poland. Very strong frost occurred particularly in the north-eastern part of the study area and in areas located at greater heights. They mainly occurred in April. In May, only 2 cases were observed in Toruń. Strong autumn frost occurred particularly in October. In September, single cases of such frost were recorded in stations located the furthest east of the study area. The strongest frost in the study area occurred in autumn approximately 5 times - usually in Białystok (33 days). A tendency for an increase in the number of cases of strong frost in Central Europe in the vegetative period is pointed to by Wypych et al. (2017).

It is assumed that despite warming trends in all seasons in Central Europe, the risk of cold spells in winter and frost days in transient seasons will still remain (Wypych et al. 2017). This is due to the Arctic amplification and the weakening of the jet stream which lead to enhanced transport of polar air masses to lower latitudes (Francis and Vavrus 2012). These circulation processes govern the occurrence of frost days in Central Europe. The average conditions favouring the occurrence of strong and very strong frost both in spring and in autumn were related to increased pressure at sea level, as suggested by positive SLP anomalies occurring over the majority of the Euro-Atlantic sector. In both seasons, detailed analyses permitted the designation of two types of circulation in each, causing the occurrence of the analysed frost. In the case of spring, in type 1, a stable baric situation was observed with a high over the British Isles, and in type 2, Europe was under the influence of two baric systems, with a high horizontal pressure gradient in between, causing intensive advection of cool air masses. In the case of autumn, in type 1, over the eastern regions of the study area, the centre of a strong high system persisted, and in type 2, the influence of the 
low from over the Scandinavia was determined over the study area and influence of a weak high over the southern regions. The obtained result are in accordance with earlier research conducted in this part of Europe (Ustrnul et al. 2014; Wypych et al. 2017), showing that the dominant baric system causing the occurrence of frost is an extensive high-pressure system over east Ukraine and Belarus, bringing continental air masses. Similarly, Tomczyk et al. (2015) determined that the occurrence of very strong frost is related to the presence of a high over Central Europe with the centre over Poland, and its presence in May causes inflow of cool air in the period of so-called Ice Saints, i.e. in the first half of May.

The occurrence of strong and very strong frost, both in spring and autumn, was related to the advection of air masses from the northern sector in general. Moreover, an important factor favouring cooling was small or lack of cloudiness, which is typical for the anticyclonic conditions. This is confirmed by the negative air temperature anomalies in the middle and lower troposphere. The greatest temperature anomalies occurred on the lowest isobaric levels, where air temperature over Central Europe was lower-than-average by even $6{ }^{\circ} \mathrm{C}$, and the centres of these anomalies were located south-east and east of the study area.

The study showed the occurrence of the greatest anomalies of geopotential heights in the upper troposphere at levels of $300-250 \mathrm{hPa}$. Over the study area, the highest values of anomalies were recorded over the eastern regions, where isobaric levels persisted even more than $170 \mathrm{gpm}$ lower than on average. It was also evidenced that the occurrence of strong and very strong frost in autumn was related to higher anomalies than in spring. A similar course of anomalies of geopotential heights was pointed to by Qian et al. (2015) analysing episodes of low air temperature in spring and autumn in the Yangtze River valley. The authors evidenced that disturbances in the upper troposphere co-occurred with strong air temperature anomalies at a level of $850 \mathrm{hPa}$. The occurrence of the greatest anomalies of heights of isobaric levels in the upper troposphere was also evidenced during other extreme weather phenomena, such as heat waves (Qian et al. 2016; Chen et al. 2017; Tomczyk et al. 2017; Tomczyk et al. 2018b; Geirinhas et al. 2019), cold waves (Qian et al. 2016; Tomczyk et al. 2018b; Tomczyk et al. 2019) and hot nights (Tomczyk 2018). Many studies evidenced (Qian et al. 2016; Chen et al. 2017) that the occurrence of extreme weather conditions is preceded by the development of disturbances in the upper troposphere, which can be helpful in forecasting such phenomena. As evidenced by Qian et al. (2015) in the case of low temperature episodes in spring and autumn in China, the disturbances developed respectively 6.9 and 10.2 days before the occurrence of the phenomenon.

Understanding the complex pressure and circulation conditions causing spring and autumn frost events may help understand weather risk in agriculture. Furthermore, with the feedback of future circulation models, it has the potential to become essential for investigating future frost day occurrence in the transient seasons.

Funding information This work was supported by the National Science Centre, Poland (grant number UMO-2017/24/C/ST10/00109).

Open Access This article is distributed under the terms of the Creative Commons Attribution 4.0 International License (http:// creativecommons.org/licenses/by/4.0/), which permits unrestricted use, distribution, and reproduction in any medium, provided you give appropriate credit to the original author(s) and the source, provide a link to the Creative Commons license, and indicate if changes were made.

\section{References}

Barlow KM, Christy BP, O’Leary GJ, Riffkin PA, Nuttall JG (2015) Simulating the impact of extreme heat and frost events on wheat crop production: a review. Field Crop Res 171:109-119

Bielec-Bąkowska Z, Piotrowicz K (2011) Variability of frost-free season in Poland in the period 1951-2006. Prace i Studia Geograficzne 47: 77-86 (in Polish)

Bielec-Bąkowska Z, Piotrowicz K, Krępa-Adolf E (2018) Trends in the frost-free season with parallel circulation and air mass statistics in Poland. Időjárás 122(4):375-392

Bonsal BR, Zhang X, Vincent LA, Hogg WD (2001) Characteristics of daily and extreme temperatures over Canada. J Clim 14:1959-1976

Buishand TA, Brandsma T (1997) Comparison of circulation classification schemes for predicting temperature and precipitation in the Netherlands. Int J Climatol 17:875-889

Burroughs WJ (2002) Gardening and climate change. Weather 5(27): $151-157$

Chen Y, Hu Q, Yang Y, Qian W (2017) Anomaly based analysis of extreme heat waves in Eastern China during 1981-2013. Int J Climatol 37:509-523

Chmielewski FM, Götz KP (2017) Identification and timing of dormant and ontogenetic phase for sweet cherries in Northeast Germany for modelling purposes. J Hortic 4:205

Chmielewski FM, Muller A, Bruns E (2004) Climate changes and trends in phenology of fruit trees and field crops in Germany. 1961-2000. Agric For Meteorol 121(1-2):69-78

Chmielewski FM, Götz KP, Weber KC, Moryson S (2018) Climate change and spring frost damages for sweet cherries in Germany. Int J Biometeorol 62:217-228

Dennis FG, Howell GS (1974) Cold hardiness of tart cherry bark and flower buds. Michigan State University farm scientists research report no. 220 of MSU

Doroszewski A, Wróblewska E, Jóźwicki T, Mizak K (2013) Evaluation of damage to fruit and horticultural plants caused by frosts in May 2011. Acta Agrophysica 20(2):269-281 (in Polish)

Dragańska E, Rynkiewicz I, Panfil M (2004) Frost frequency and intensity in north-eastern Poland in 1971-2000. Acta Agrophysica 3(1): 35-41 (in Polish)

Dudek S, Żarski J, Kuśmierek-Tomaszewska R (2012) Trends in the occurrence of ground frosts in the region of Bydgoszcz. Woda Środowisko - Obszary Wiejskie 12(2):93-106 (in Polish)

Easterling DR (2002) Recent changes in frost days and the frost free season in the United States. B Am Meteorol Soc 83:1327-1332

Francis JA, Vavrus SJ (2012) Evidence linking Arctic amplification to extreme weather in mid-latitudes. Geophys Res Lett 39:L06801

Geirinhas J, Trigo RM, Libonati R, Castro LCO, Sousa PM, Coelho CAS, Peres LF, Magalhães MAFM (2019) Characterizing the atmospheric conditions during the 2010 heatwave in Rio de Janeiro marked by excessive mortality rates. Sci Total Environ 650:796-808 
Goergen K, Beersma J, Hoffmann L, Junk J (2013) ENSEMBLES-based assessment of regional climate effects in Luxembourg and their impact on vegetation. Clim Chang 119:761-773

Graczyk D, Kundzewicz ZW (2016) Changes of temperature-related agroclimatic indices in Poland. Theor Appl Climatol 124(1-2): 401-410

Heino R, Bràzdil R, Førland E, Tuomenvirta H, Alexandersson H, Beniston M, Pfister C, Rebetez M, Rosenhagen G, Rösner S, Wibig J (1999) Progress in the study of climatic extremes in Northern and Central Europe. Clim Chang 42(1):151-181

Huth R, Beck C, Philipp A, Demuzere M, Ustrnul Z, Cahynova M, Kysely J, Tveito OE (2008) Classifications of atmospheric circulation patterns: recent advances and applications. Ann N Y Acad Sci 1146:105-152

IPCC (2013) Climate change: the physical science basis. Contribution of Working Group I to the Fifth Assessment Report of the Intergovernmental Panel in Climate Change. Cambridge University Press, Cambridge

Jylhä K, Fronzek S, Toumenvirta H, Carter TR, Ruosteenoja K (2008) Changes in frost, snow and Baltic Sea ice by the end of the twentyfirst century based on climate model projections for Europe. Clim Chang 86:441-462

Kalma JD, Laughlin GP, Caprio JM, Hamer PJC (1992) The bioclimatology of frost. Its occurrence, impact and protection. Advances in bioclimatology 2. Springer-Verlag, Berlin Heidelberg

Kalnay E, Kanamistu M, Kistler R, Collins W, Deaven D, Gandin L, Iredell M, Saha S, White G, Woollen J, Zhu Y, Leetmaa A, Reynolds R, Chelliah M, Ebisuzaki W, Higgins W, Janowiak J, Mo KC, Ropelewski C, Wang J, Jenne R, Joseph D (1996) The NMC/NCAR 40-year reanalysis project. B Am Meteorol Soc 77: $437-471$

Kossowska-Cezak U (2003) Contemporary warming and the frequency characteristic days. Balneologia Polska 45(1-2):92-100 (in Polish)

Koźmiński C, Trzeciak S (1971) Distribution of spring and autumn groundfrost in Poland in respect to space and time. Przegląd Geograficzny 43(4):523-549 (in Polish)

Kreyling J, Thiel D, Simmnacher K, Willner E, Jentsch A, Beierkuhnlein C (2012) Geographic origin and past climatic experience influence the response to late spring frost in four common grass species in central Europe. Ecography 35:268-275

Kunkel KE, Easterling DR, Hubbard K, Redmond K (2004) Temporal variations in frost-free season in the United States: 1895-2000. Geophys Res Lett 31:L03201

Liu B, Henderson M, Xu M (2008) Spatiotemporal change in China's frost days and frost-free season, 1955-2000. J Geophys Res 113: D12104

Longstroth M, Perry RL (1996) Selecting the orchard site, orchard planning and establishment. In: Webster AD, Looney NE (eds) Cherries: crop physiology, production and uses. CAB International, Cambridge, pp 203-221

Matzneller P, Götz KP, Chmielewski FM (2016) Spring frost vulnerability of sweet cherries under controlled conditions. Int J Biometeorol 60(1):123-130

Meehl GA, Tebaldi C, Nychka D (2004) Changes in frost days in simulations of twentyfirst century climate. Clim Dyn 23:495-511

Miranda C, Santesteban LG, Royo B (2005) Variability in the relationship between frost temperature and injury level for some cultivated Prunus species. Hortscience 40(2):357-361

Niedźwiedź T (2000) The dynamics to selected extreme climatic events in Poland. Geogr Pol 73:25-39
Potop V, Zahradniček P, Türkott L, Štěpánek P, Soukup J (2014) Risk analysis of the first and last frost occurrences during growing season of vegetables in the Elbe River lowland. Időjárás 118(1):1-17

Proebsting EL (1982) Cold resistance of stone fruit flower buds. Cooperative Extension of Washington State University, Washington

Proebsting EL, Mills HH (1978) Low temperature resistance of developing flower buds of six deciduous fruit species. J Am Soc Hortic Sci 103:192-198

Qian W, Chen Y, Jiang M, Hu Q (2015) An anomaly-based method for identifying signals of spring and autumn low temperature events in the Yangtze River Valley, China. J Appl Meteorol Climatol 54: 1216-1233

Qian WH, Yu TT, Du J (2016) A unified approach to trace surface heat and cold events by using height anomaly. Clim Dyn 46(5):1647-1664

Rigby JR, Porporato A (2008) Spring frost risk in a changing climate. Geophys Res Lett 35:L12703

Scheifinger H, Menzel A, Koch E, Peter C (2003) Trends of spring time frost events and phenological dates in Central Europe. Theor Appl Climatol 74:41-51

Schnelle F (1963) Frostschutz im Pfnazenbau. Quellenwerk über den Nachtfrost, seine Entstehung und Abwehr. Band 1, Die meteorologischen und biologischen Grundlagen der Frostschaden verhüttung. BLV Verlagsgesellschaft, München, Basel, Wien

Tomczyk AM (2018) Impact of atmospheric circulation on the occurrence of hot nights in Central Europe. Atmosphere 9(12):474

Tomczyk AM, Szyga-Pluta K (2018) Variability of thermal and precipitation conditions in the growing season in Poland in the years 19662015. Theor Appl Climatol 135(3-4):1517-1530

Tomczyk AM, Szyga-Pluta K, Majkowska A (2015) Frost and frost-free periods in Poland and neighbouring countries. Open Geosci 7(1):812-823

Tomczyk AM, Półrolniczak, Bednorz E (2017) Circulation conditions' effect on the occurrence of heat waves in western and southwestern Europe. Atmosphere 8:31

Tomczyk AM, Szyga-Pluta K, Bednorz E (2018a) The effect of macroscale circulation types on the length of the growing season in Poland. Meteorog Atmos Phys. https://doi.org/10.1007/s00703018-0639-9

Tomczyk AM, Bednorz E, Półrolniczak M, Kolendowicz L (2018b) Strong heat and cold waves in Poland in relation with the largescale atmospheric circulation. Theor Appl Climatol. https://doi.org/ 10.1007/s00704-018-2715-y

Tomczyk AM, Bednorz E, Sulikowska A (2019) Cold spells in Poland and Germany and their circulation conditions. Int J Climatol 39: 4002-4014. https://doi.org/10.1002/joc.6054

Ustrnul Z, Czekierda D, Wypych A (2010) Extreme values of air temperature in Poland according to different atmospheric circulation classifications. Phys Chem Earth 35:429-436

Ustrnul Z, Wypych A, Winkler JA, Czekierda D (2014) Late spring freezes in Poland in relation to atmospheric circulation. Quaestiones Geogr 33(3):165-172

Ward JH (1963) Hierarchical grouping to optimize an objective function. J Am Stat Assoc 58:236-244

Wibig J (2001) The influence of atmospheric circulation on spatial distribution of air temperature and precipitation anomalies over Europe. Wyd. Uniwersytetu Łódzkiego, Łódź

Wypych A, Ustrnul Z, Sulikowska A, Chmielewski FM, Bochenek B (2017) Spatial and temporal variability of the frost-free season in Central Europe and its circulation background. Int J Climatol 37:3340-3352 